\title{
On the Bilingual Teaching Reform in China: A Look into Sino-U.S Bilingual Education
}

\author{
Baoren $\mathrm{Su}$ \\ Tourism and City Administration College, Zhejiang Gongshang University \\ Hangzhou 310018, China \\ E-mail: baorens@yahoo.com
}

Received: February 19, $2011 \quad$ Accepted: March 19, 2011 doi:10.5539/ijel.v1n2p264

\begin{abstract}
China is increasingly opening its door to the outside world and is actively making connection with the international community economically, culturally and politically. Within such a context, Chinese education, higher learning education in particular, is undergoing a profound reform trying to keep pace with the development of international education, especially the US education system, to train Chinese students to cope with international competition with the bilingual ability as the era of global economic integration and knowledge economy knock at the door of China. The purpose of this paper is to explore the way of how to reform the bilingual teaching in China and, at the same time, make a comparison of Sino-US bilingual education.
\end{abstract}

Keywords: Bilingual teaching, Sino-U.S bilingual education

\section{Introduction}

How to improve China's bilingual teaching methods in university is under hot debating today. This study was taken in view of the similarity as well as the differences of bilingual education system between China and United States in order to find the way of how to reform the bilingual teaching education in China. Significant differences and similarities were found in mechanism and perceptions about bilingual education in two countries. It is because that there are lots of things in common for China and the U. S. to have similar purposes in providing bilingual education for their students respectively. Bilingual education seeks to develop a foundation of a purposeful, productive, and fulfilling life and a just, compassionate, and flourishing society. For most Chinese people, especially the college students, they treat bilingual education as a means for what they want get for better and more in future. The research work in this field should be done before we learn how bilingual education may be usefully and efficiently provided to different people with various educational needs.

Bilingual language simply means having two languages and they are all bilinguals possessing different degrees of bilingualism. A bilingual's degree of bilingualism is assessed in the skills of listening comprehension, speaking, reading comprehension and writing. For each skill there could be differing abilities in each language, for example, an English Chinese bilingual educated through English could be much more proficient at writing English than Chinese, while his spoken Chinese could be better than his spoken English. So we can say that a bilingual people range from one who is indistinguishable from a native speaker in both languages at one end to the person who has just begun to acquire a second language at the other end. There are many possible combinations of abilities in these skills. As an integral part of modern education in China, bilingual education has been given a fully new meaning nowadays when China is trying every effort in pursuing economic, political and social reform, and modern science and technology is playing decisive roles in the social and economic development. We know that there are many reasons why the American society is growing so quickly in a variety of ways, but the one important reason is its bilingual education. What is the characteristic of America's bilingual education compared with China's one? How does it make so much of achievement in this field? Compared with the bilingual education practiced in United States, China's bilingual education is quite later in its development, and therefore, needs to learn and borrow America's experiences in its development and cultivation of bilingual education mechanism. For about two hundreds of years, the United States has been developing into a modern country, becoming today's super power and playing an increasingly important role in the world's course of development. As a superpower of science and technology and education in the world, American government has always attached primary importance to developing and improving bilingual education mechanism, and established a complete set of nationwide bilingual education mechanism. Therefore, it is significant to make a research and look into the mechanism of Sino-U.S bilingual education

\section{The course of development and current state of U.S bilingual education}

The America is an immigrant country, and with more and more immigrants from all over the world moving to America since 1960s, the size of immigrant population has got huge expansion. As the minority group, they have very strong desire to learn to survive a new social and economic environment. However, they could not very well 
understand its language, let alone American culture, because of their lower educational level. On the other hand, the American social and economic development itself needs to transform them, a huge labor force, into human resources to help contribute to its further development. To do so needs American government to provide bilingual education for them, including adult education, vocational technical education, long-distance correspondence education, community college education, T.V university long-distance education and so on. That made them feel it needed to receive bilingual education for the different groups of people who are attending bilingual school, and most of them are from various groups of immigrants who are naturalized as American citizens.

How to enhance the global competitive power of American economy has become the starting point of American educational policy, as education has been regarded by American government as one of the best means to enhance labor productivities, especially with the coming of global economic integration and knowledge economy. On the other hand, how to make American original structure of labor productive technology and knowledge fit for the global economic competition has become increasingly urgent for American government to find a solution. While it has been advocated by the American society to achieve success through personal hard work and study, more and more Americans today, old and young, male and female, have made the continuous education throughout their lives increasingly become a well-received social value as well as a shortcut in their efforts to make success. The traditional one-time education concept can no longer meet what they desire to make their dream for personal success come true, which means a great amount of labor forces are to be reeducated for the new knowledge and new skills by means of education. The U. S. government pushes Americans to learn foreign languages such as Chinese, Arabian, and Japanese as national long-term goal in education policy. In a number of school districts, Two-Way bilingual education programs at the middle school and elementary school level become the favorite where parents have the vision of future benefits for their children and schools have the ability to provide bilingual education. Therefore, bilingual education, as a form of continuous education of American society, has not only become a means to make a living in modern society, what is more, become what they can count on in realization of their dream of life.

\section{The current state of China's bilingual education}

Nowadays, there is a requirement in China's colleges and universities to provide bilingual education in various fields, especially in business management, finance, political science, natural sciences, and engineering. There are two purposes for bilingual teaching, the first is to enable China's college students to get advanced sciences and technologies directly from those English-speaking countries with a foreign language, and the second is to help them to develop bilingual language skills for efficient worldwide communication. However, the foreign language learning environment in Chinese colleges and universities does not favor the bilingual teaching as a means of communication in classroom, as the attitude of utilitarian towards learning English restrains, more or less, many Chinese students to fully understand and appreciate the cultures of bilingual education which may make them interested. The guidelines provided by the Ministry of Education of China stipulates that schools ought to adopt authentic English textbooks published in such countries as the United States and other English-speaking countries where sciences and technologies are relatively more advanced. In some sense, Bilingual education means a teacher lectures in classroom in English. Therefore, a bilingual teacher must not only have expertise in his or her field of subjects, but also must be fluent in English speaking and writing. Within such context, a bilingual teacher should have both professional knowledge and a good English foundation, which, however, is unavailable in many universities today in China, not mention middle schools or primary school. The issue about how to establish the curriculum of bilingual education and how to evaluate it has no answer so far. The teaching method, the feature, the mode and the environment of bilingual education is still under experiment and discussion. Many colleges and universities require that, if it is a class taught in English, any explanation written on the chalkboard must also be in English. The students who have a limited English proficiency feel difficult to comprehend proper academic contents of their field with lots of problems remaining on its feasibility, effectiveness, and necessity. In fact, it is clear that the utilitarian nature of China's collegiate bilingual education is highly dependent on the qualifications of the faculty and the capacity of the students, which indicates that China's collegiate bilingual education is a mixture of immersion of English learning and transitional English study approach.

The economic tide of globalization has without any exception got China involved in the international economic competition. The global economy integration and international relations has revitalized bilingual education in China. As a new member of the World Trade Organization (WTO), China is trying to take advantage of this opportunity to meet the challenges. With the development of China's economy and society, especially with the conceptual and ideological change of Chinese people, the idea of bilingual education has been gradually accepted by more and more of people, especially young students. The global economic competition, putting it in other words, is, in fact, a competition for talent people with higher degree of education. Bilingual education is an advanced learning idea. However, the old traditional idea of "education for one-time being useful for all one's life" is still prevailing in today's educational market. Comparatively speaking, Chinese people's idea for education is still predominated by orthodox and conservative idea, and takes education just as a means for 
obtainment of diploma and degree, which in turn, make it very difficult to thoroughly popularize the idea of bilingual education. Chinese teachers are expected to play the role of not only teaching responsibility but also example of morality, which means that Chinese teachers needs to be concerned about students' academic performance, take care of students' daily life and safety, focus on students' ideological idea and plan students' lifetime goals after graduation. Under the background of Chinese traditional culture, the Chinese teachers not only need to teach students but also need to "foster" students. In some sense, the roles played by Chinese teacher is the overlapping roles of both teacher and parent, and idea of "respecting teacher as sage" is the common attribute for most of Chinese students and teachers. They seldom go beyond the limits of working relationship between teacher and student to mold students in accordance with their own model of idea. That is why the good relationship between teacher and student is often dubbed as "relationship as inseparable as father and son" or "relationship as inseparable as mother and daughter". In contrast, what the American teachers do for their students in some more sense is to offer help and suggestions which usually focus on where teachers and students have common concerns and interests.

As English serves as a kind of "global language" in the current global communication, it is natural for China, a country that strives for a better national image in the international arena, to train its students to work in both English-speaking and Chinese-speaking countries. For most of Chinese students, bilingual education is a ladder for a higher level of society, a useful tool, and a pass to the better outside world. It is because that first, it is a result of the English dominance in the area of international communication and Second, foreign language and cultural differences are viewed as two major barriers for effective communication with outside world, especially English-speaking world. Bilingual education is training those people who wish to be able to command English for worldwide business and communication. However, the governments, especially the education administrations concerned, fail to make an overall plan in mapping out the policy of developing bilingual education, especially fails to establish a long-term bilingual education policy with concrete workable measures, which has great bearing on the long-term healthy development of bilingual education to guarantee the bilingual education mechanism as well as the enforcement of bilingual education policy..

\section{The problems in development of China's bilingual education}

It is clear that in order to meet the needs of implementing the bilingual education in colleges and universities across China, bilingual instructors need to be "retrained" from time to time at a foreign university to update their professional knowledge about latest development of their field of subjects and, the teaching materials for bilingual education ought to be updated for effective teaching. However, when Chinese government decided to carry out so-called market economy, it became more and more difficult for Chinese school authorities to keep the already-limited number of bilingual instructors to remain on campus because they are free to resign their teaching jobs and go to somewhere else where they can find much better-paid jobs. On the other hand, the heavy working load and stress faced by Chinese teachers and the lack of funding invested in colleges make it difficult to organize this kind of retraining at bilingual training programs in China, which, to some degree, have made qualified bilingual teachers today unqualified tomorrow. We should be aware that there are no models, such as American Two-Way or Canadian Immersion bilingual teaching approaches, that are perfect enough for the Chinese teachers to copy. However, in contrast, American governments have strict regulations on bilingual teacher qualification. The priorities in people's education may have to be different as we are from different economic, educational, and linguistic backgrounds. It is extremely important to create a good bilingual teaching and learning environment, in which teachers and students should be both bilingual in order to successfully carry out efficient bilingual teaching in a Chinese context, so there is no reason to seek international standards in bilingual education that combine with cultural values, personal preferences, social needs, and public choices. It is helpful for us to know the differences in bilingual education between China and the United States. Most American bilingual teachings are for limited English proficient children, and have depended upon local government efforts, while in China, bilingual teachings in colleges and universities are fully funded by the central government.

On the other hand, few English periodicals, newspapers and academic journals are available in most Chinese colleges and universities, and most bilingual teaching programs in China lack effective access to updated teaching materials from English-speaking countries. The Chinese college students could hardly afford to buy textbooks edited in English, and new textbooks are often not available. Therefore, bilingual instructors are often restrained in finding latest materials for their teaching and research, which obstruct their teaching quality and their research activities. This makes it difficult to create an effective bilingual teaching and learning environment in that the Chinese students who are not yet proficient in English cannot fully understand the lectures, let alone speak and write well in English, while bilingual teachers can feel very frustrated as students may literally translate from Chinese into English. They are expected to become competent enough to use bilingual language for either academic work or social life.

\section{The U.S bilingual education strategy of development}

The American government takes Bilingual education both as a social systematic project and a complicated educational systematic project, and draws up a series of flexible education measures and plans and developed a 
set of standing effective mechanisms of bilingual education, which is characteristic of richness in contents, completeness in structure, and variety in forms. It specifically drew up a series of policies and plans for bilingual education as the subject of priority for development and research, reinforcing its macroscopic regulation and supervision for bilingual education, the purpose of which is to allow full play to the initiative of local social organizations in development of character education, and in the meantime, to reduce the blindness of people's engagement in education. The function of teachers in American education and culture is to help their students to make a self-realization and to gain knowledge and skills in their studying process. American teachers combine self, subject, and students in the fabric of life because they teach from an integral and undivided self; they manifest in their own lives, and evoke in their students, a "capacity for connectedness." On the other hand, the American government spares no efforts to intensify its financial support and policy support in promotion of bilingual education, and always takes it seriously that bilingual education is a systematic social project and needs various social organizations and industrial and commercial enterprises to get involved to support bilingual education. The U.S government financial assistance also includes the bilingual education scholarship, non-interest student loans, and subsidies of study. It stipulates that all social organizations and industrial and commercial enterprises can enjoy the preferential educational policy, the reduction of education taxation and non-interest financial assistance provided by three levels of governments on condition that they take part in opening and managing bilingual education.

On the other hand, American teachers would not get involved in helping design life future for students, but rather, they would play the roles of mentor of students - giving attention to students' daily learning problems, and offering their help and suggestions. The daily life of classrooms as well as all other parts of the school environment is imbued with core values such as concern and respect for others, responsibility, kindness, and fairness. The American school itself embodies a good character and it does this by becoming a moral community that helps students form caring attachments to adults and to each other. The methods used by them vary widely: lectures, collaborative problem-solving. The connections made by American teachers are held not in their methods but in their hearts -- the place where intellect and emotion and spirit will converge in the human self. It progresses towards becoming a microcosm of the civil, caring, and society we seek to create as a nation. All students have a need to belong, and they are more likely to internalize the values and expectations of groups that meet this need, for these caring relationships will foster both the desire to learn and the desire to be a good person, and are able to weave a complex web of connections between themselves, their subjects, and their students.

\section{Conclusion}

The importance of bilingual education has gone beyond the significance of education itself both in terms of its theory and in terms of its practice. The mechanism of management and research in Chinese bilingual education remains much rooms for improvement. The development of bilingual education not only needs the support from policy and law but also needs financial support from government. With China entering an intellect-based economic era today, the bilingual education has been taken as an important education policy to revitalize China by virtue of education and science. The participation of Chinese social organizations in the bilingual education is far from achieving the social effects as a whole, and much of efforts in developing bilingual education have still been made by Chinese government alone, which is very difficult to accomplish the task of constructing a relatively perfect mechanism of bilingual education. Generally speaking, Chinese education is centered on the book knowledge with academic examination as its major focus, which is not instrumental to the cultivation of creative capability. It is because there have been so far no specific policy for bilingual education that Chinese government is not likely to financially support bilingual education as the U.S government does. Bilingual education takes deliberate steps to cultivate intellectual virtues through every phase of school life- the relationships among peers, the content of the curriculum, the process of instruction, the rigor of academic standards, the environment of the school, the conduct of extracurricular activities, and the involvement of parents. The first step of management mechanism is to set up and improve the system of educational assessment, which is a key link to verify and guarantee the quality of bilingual education. The American bilingual education system has a lot of useful practices for us to borrow and learn. Educational systems today are focused on raising standards of academic achievement. However, as we consider the world in which we live, we understand the importance of helping students to learn much more than the subjects they study. Appropriate environments, activities, the arts, and service projects can help students to learn responsibility, compassion, integrity, civility, leadership and cooperation. These and other elements of healthy, well-developed education system can be learned by example and opportunity to exercise them. Everything that happens in the life of the school is instructive, because everything affects the healthy growth of students. It will be advisable for us to learn and make a research into America's bilingual education, for there exist great differences between two countries on either teaching idea of education or teaching mode. The different cultural tradition of America and China affects two countries' ideas and concepts of bilingual education. The Chinese government needs to establish a set of complete national scientific system of assessment for bilingual education in order to promote the orderly and healthy development of it. It is hoped that Chinese bilingual education will get much improvement by drawing on the beneficial experiences of American bilingual education system. 


\section{References}

Benson, P. (2005). Teaching and Researching Autonomy in Language Learning. Beijing: Foreign Language Teaching and Research Press.

Brown, H., Douglas. (2001). Teaching by Principles: An Interactive Approach to Language Pedagogy. Beijing: Foreign Language Teaching and Research Press.

Cameron, L. (2001). Teaching Languages to Young learners. Cambridge: Cambridge University Press.

Chaudron, C. (1988). Second language classrooms: research on teaching and learning. Cambridge: Cambridge University Press.

Chen, H. \& Zhang, Y. F. (2001). A Study on Chinese Children's English Vocabulary Strategies. Foreign Language Research, No. 4.

Cohen, A. D. (2000). Strategies in Learning and Using a Second Language. Foreign Language Teaching \& Research Press.

Corder, S. P. (1979). Language distance and the magnitude of the learning task. Studies in Second Language Acquisition, 2, 27-36. doi:10.1017/S0272263100000930, http://dx.doi.org/10.1017/S0272263100000930

Crookes, G. (1989). Planning and interlanguage variation. Studies in Second Language Acquisition, 11, $367-383$. doi:10.1017/S0272263100008391, http://dx.doi.org/10.1017/S0272263100008391

Day, R. R. and Bamford, J. (1998). Extensive reading in the second language classroom. Cambridge: Cambridge University Press.

Deng, Yuan \& Yang, Zhiqing. (2004). The role of learner factors in listening comprehension. Educational Technology for Foreign Language Teaching, (1).

Ellis, R. (1985). Understanding second language acquisition. Oxford: Oxford University Press.

Gallaway, C. \& B.J. Richards. (1994). Input and interaction in language acquisition. UK: Cambridge University Press.

Garrett, N. (1986). The problem with grammar. Modern Language Journal, 70, 133-47. doi:10.2307/327318, http://dx.doi.org/10.2307/327318

H, H, Stern. (1996). Issues and Options in Language Teaching. Shanghai Foreign Language Education Press.

Hung, E. (2002). Translation and English in twentieth-century China. World English, 21, 326-35. doi:10.1111/1467-971X.00252, http://dx.doi.org/10.1111/1467-971X.00252

Li, Xiaolong. (1988). Effects of contextual cues on inferring and remembering meanings of new words. Applied Linguistics, 9, 402-413. doi:10.1093/applin/9.4.402, http://dx.doi.org/10.1093/applin/9.4.402

Li, Xiaomei. (2006).On bilingual education of higher learning schools. Journal of Science Education of Higher Learning, 68(4):122-124.

McArthur, T. (1983). A Foundation Course for Language Teachers. Cambridge: Cambridge University Press.

Moore, G.M., \& Kearsley, G. (1996). Distance Education: A Systems View. Belmont: Wadsworth Publishing Company.

Richards, Jack C. and Nunan, David (eds). (1990). Second Language Teacher Education. Cambridge: Cambridge University Press.

Richards, J. C. \& C. (2000). Lockhart. Reflective Teaching in Second Language Classrooms. Beijing: Foreign Language Teaching and Research Press.

Shu, Dingfang \& Z. Zhuang. (1999). Modern language teaching---theories, practice and methods. Shanghai Foreign Language Education Press.

Swain, M., \& Lapkin, S. (2000). Task-based second language learning: The uses of the first language. Language Teaching Research, 4(3), 251-270.

Thomas, P. (2006). Preservice practicum teaching in Central Asia: A positive experience for both worlds. Journal of Social Studies Research, 30(1):21-25.

Walberg, H. J. (1985). The relation of parenting style to adolescents' school performance. Journal of Education, 62:18-41.

Wen, Qiufang. (1996). Studies on English Learning Strategies. Shanghai Foreign Language Education Publishing House.

Widdowson, H. G. (1978). Teaching language as communication. Oxford: Oxford University Press.

Widdowson, H. C. (1979). The communicative Approach and its Applications. Oxford University Press.

Xiao, Liquan. (2006). English Teaching Methodology. Beijing: Foreign Language Teaching and Research Press.

Yan, Zhiqiang. (2002). An Outline of World Englishes. Beijing: Foreign Language Teaching and Research Press.

Zhang, X. (2007). The organizational strategies of collaborative learning in English Classroom. Foreign Language and Their Teaching, (8):38-39. 